\title{
U.S. Spanish-Language Television Management during the Industry's First 50 Years
}

\section{Kenton T. Wilkinson ${ }^{1}$ Daniela Contreras-Díaz ${ }^{2}$}

Recibido: 2014-06-13

Enviado a pares: 2014-06-15
Aprobado por pares: 2014-09-10

Aceptado: 2014-10-02

DOI: 10.5294/pacla.2014.17.4.8

Para citar este artículo / To reference this article / Para citar este artigo

Wilkinson, K. T., Contreras-Díaz, D. Diciembre de 2014. U.S. Spanish-Language Television Management during the Industry's First 50 Years. Palabra Clave 17(4), 1168-1193. DOI: 10.5294/pacla.2014.17.4.8

\section{Abstract}

Many people were stunned to learn the Spanish-language television network Univision was the highest rated in prime time among all U.S. networks in July 2013, a feat it repeated a year later. Steady growth of its demographic and advertising bases, combined with astute management, has brought success to this dynamic industry sector. However, the boom years were preceded by several decades of formidable challenges and lean periods. This article examines the principal technological, programming, financial and competitive obstacles network management faced from the 1970s to the 2000s, illustrating the variety of fronts on which ethnic-oriented media leaders maneuvered during a period of rapid population growth and industry transformation.

\section{Keywords}

Programming content, industrial transformation, information industry, media control. (Source: Unesco Thesaurus).

1 Texas Tech University, Estados Unidos. kent.wilkinson@ttu.edu

2 Texas Tech University, Estados Unidos. daniela.contrerasdiaz@ttu.edu 


\section{Gestión de televisión en español en los Estados Unidos durante los primeros 50 años de la industria}

\section{Resumen}

Muchas personas se sorprendieron al enterarse de que Univisión, la cadena de televisión en español, hubiese tenido el más alto rating en el horario estelar entre todas las redes de los Estados Unidos en julio de 2013 -una hazaña que se repitió un año más tarde-. El crecimiento constante de sus bases demográficas y de publicidad, combinado con una astuta gestión, ha llevado al éxito a este sector dinámico de la industria. Sin embargo, a los años de auge le precedieron varias décadas de desafíos formidables y de periodos de escasez. Este artículo examina los principales obstáculos tecnológicos, de programación, financieros y competitivos a los cuales se enfrentó la gestión de redes desde la década de los setenta a la década del 2000, e ilustra la variedad de frentes dentro de los cuales maniobraron los líderes de los medios de comunicación orientados hacia lo étnico durante un periodo de acelerado crecimiento de la población y transformación de la industria.

\section{Palabras clave}

Contenido de programación, la transformación de la industria, industria de la información, el control de los medios de comunicación. (Fuente: Tesauro de la Unesco). 


\section{Gestão de televisão em espanhol nos estados unidos durante os primeiros 50 anos da indústria}

\section{Resumo}

Muitas pessoas se surpreenderam ao saberem que a Univisión, a rede de televisão em espanhol, tivesse tido a mais alta audiência em horário nobre entre todas as redes dos Estados Unidos em julho de 2013 -uma façanha que se repetiu um ano mais tarde-. $\mathrm{O}$ crescimento constante de suas bases demográficas e de sua publicidade, combinado com uma astuta gestão, levou esse setor dinâmico da indústria ao sucesso. Contudo, aos anos de auge, precederam-lhe várias décadas de desafios formidáveis e de períodos de escassez. Este artigo examina os principais obstáculos tecnológicos, de programação, financeiros e competitivos que a gestão de redes enfrentou desde a década de 1970 à de 2000, e ilustra a variedade de frentes dentro das quais manobram os líderes dos meios de comunicação orientados ao étnico durante um período de acelerado crescimento da população e transformação da indústria.

\section{Palavras-chave}

Conteúdo de programação, transformação da indústria, indústria da informação, controle dos meios de comunicação. (Fonte: Tesauro da Unesco). 
Throughout the more than 50-year history of the Spanish-language television industry in the United States, network management has faced challenges to the growth, stability and even survival of its enterprises. Such trials have come in irregular waves, typically associated with economic fluctuations, regulatory developments, industry changes or technological shifts. This article identifies the more salient challenges and examines how management responded at the two principal Spanish-language television networks based in the U.S.: Univision and Telemundo. ${ }^{3}$ Some problems, such as economic downturns and the accompanying tightening of credit or the emergence of new media platforms like the Internet, affect all media regardless of size, language or target audience. Other challenges such as forced divestiture due to excessive station control by foreign nationals, insufficient access to inexpensive foreign-produced programming, and audiences' shifting language preferences are unique to ethnic-oriented media. Following a brief review of relevant literature in media management, we present and discuss five periods between the 1970s and the 2000s when the directors of Spanish-language television enterprises confronted, and survived, significant challenges.

\section{Media Management}

We should begin by noting the media management field faces definitional problems. Küng asserted, "The field of media management is neither clearly defined nor cohesive" (2008, p. 3), and Albarran (2008) admitted difficulty in defining the field even after years of editing the International Journal on Media Economics. In an assessment of the first 75 years of media management and economics research, Albarran (2013) concluded that theory unique to the media management field had yet to emerge, a circumstance that would impede the field's development if not addressed. Thus, it should come as little surprise that there is limited literature regarding how general market television network managers strategically respond to specific threats facing their enterprises, and such literature focused on ethnic-oriented te-

3 Azteca América, the U.S. branch of Mexico's Televisión Azteca network, has gained audience since its launch in 2001. As a more recent arrival, it is not included in this analysis; the interested reader may consult Piñon (2007; 2011) and/or Wilkinson (forthcoming) for more information. 
levision in the U.S. is all but non-existent. Some applicable broad research does, however, exist.

Picard (2004) defines corporate strategy as "the result of planning and decisions to sustain patterns of resource allocation to meet challenges in the marketplace" (p. 2). Clearly, the breadth and quality of information from both within and outside the organization have direct impact on managers' planning and decision-making processes. Thus, scholarship on the strategic management of media firms focuses on external as well as internal factors to understand why some media companies outperform their competitors (Mierzjewska \& Hollifield, 2006). Among the external factors, Picard (2004) pinpoints two as being particularly influential. Market complexity refers to degrees of difficulty organizations face when navigating their markets. We shall see that the two principal U.S. Spanish-language television companies faced increasing market complexity during the decades under scrutiny herein, especially as the impacts from digitization began accelerating in the late 1980s. Market turbulence results from instability or unclear direction in a market, and hampers managerial efforts to reduce uncertainty (Picard, 2004; Sylvie, Wicks, Hollifield, Lacy \& Sohn, 2008). Turbulence characterized Spanish-language television in the U.S. during most of the 1980s, as two legal processes claimed the arrival of Spanish International Network (now Univision) and Telemundo introduced sustained competition in the industry. Instability also prevailed during the first half of the 1990s, as financial uncertainty rocked both major networks.

Küng (2008) argues the major strategic challenges facing the television industry over the past several decades involve the introduction of digital technology. The easing of spectrum scarcity through digitization led to a proliferation of channels (supply) that was not matched by growth in audiences (demand). Digitization also introduced new forms of electronic entertainment such as the Internet and gaming, which competed with television for audiences' time and attention. Such competition placed more pressure on television enterprises to define and understand their audiences. Spanish-language television had been compelled to do this almost since its inception, as many potential advertisers were skeptical of the medium's ability to deliver consumers. An important distinction from the general mar- 
ket, however, was the steady increase in the number and spending power of U.S. Hispanics from the 1980s onward. Much of the emphasis on the Hispanic youth market in the 2000s derived from the complexities of its cultural and linguistic orientations and preferences, not just its familiarity with digital technology.

We should emphasize that, although most of the examples discussed below focus on management responses to external factors, internal dynamics also have been influential. Stockholder strife, tensions surrounding managers' ethnicity, employee dissatisfaction and other strains have impacted station and network management as well (Wilkinson, forthcoming). ${ }^{4}$

Given the real and potential challenges originating with a variety of sources at an accelerated pace, as Sylvie et al. (2008) point out, "Media leaders today must be insightful, adaptable and strategic in their actions" (p.46).

\section{Responding to Distribution Challenges with Technology}

Although there were prior examples of television broadcasting in Spanish, the first sustained efforts at developing an industry in the U.S. began in the early 1960s when Mexican media entrepreneur Emilio Azcarraga Vidaurreta and his fellow investors purchased stations and began to develop a station group, Spanish International Communications Corp. (SICC), and a programming and advertising sales network to support the stations, Spanish International Network (SIN). The first SICC stations were located in San Antonio (1961), Los Angeles (1962) and New York (1968), spanning the breadth of the country and posing a significant program distribution impediment. We will return to them following a brief discussion of a reception technology issue.

The SICC stations were just beginning to broadcast on the ultra high frequency (UHF) band when the Federal Communications Commission's All-Channel Receiver Act (1961) required that all new television sets sold in the U.S. include built-in UHF reception capability. Thus, viewers who

4 Space limitations prevent us from examining these in depth. 
already owned sets or bought used ones without UHF capability were required to buy a converter costing between 40 and 70 dollars-no minor investment at the time-in order to receive Spanish-language broadcasts. Significantly, Spanish-speaking viewers' willingness to purchase the converters also signaled their desire to tune-in Spanish broadcasts over the long term, a selling point that SIN representatives could emphasize to advertisers.

Broadcasting on the UHF band was a sound strategic decision, because English-language broadcasters located in key Hispanic markets had lost faith in it and were eager to sell their stations. Rather than reaching two or three markets on the costlier VHF band, the UHF stations allowed SICC to enter five markets for around the same level of investment. Thus, Spanish International became the first U.S. company to form a national television network based on UHF technology.

Also key to establishing national network status was Spanish International's initiation of satellite-based programming distribution in 1976. Initially, the satellite system functioned by receiving a terrestrial microwave signal from Mexico in San Antonio and uplinking it to a Weststar satellite, which transmitted the signal back down through its broad footprint. Later, after Ronald Reagan deregulated the U.S. satellite market (1984) and Mexico's Morelos satellite began service (1985), SIN became less reliant on terrestrial microwave feeds and more satellite options emerged within the U.S. Satellite technology facilitated the distribution of pre-recorded programming, made the simulcast of live shows in Mexico possible, and fostered the development of the first domestically-produced national Spanish-language newscast in the U.S. These advantages further reinforced Spanish International Network's already dominant position in the industry. In 1983, Spanish International executives began developing a proprietary satellite system called PanAmSat, which would become the first privately held satellite company with worldwide coverage and a major player in transnational television distribution.

We should emphasize Spanish International leadership's deft use of the U.S. legal system to support the companies' technological strategies. A 
so-called "carrier-of-the- week" system limited the transmission of television programs between the U.S. and other nations to four telecommunication heavyweights: Western Union International, RCA Global Communications, ITT Worldcom and AT\&T. They took turns as the domestic purveyors of TV signals transmitted from overseas by Comsat. Thus, companies such as SIN were obligated to use the designated "carrier-of-the-week" in order to receive their signal from a Comsat earth station. In petitioning for the abolition of this and other middleman services, SIN was joined by major businesses and organizations with international communication interests, including the three major English-language television networks and the U.S. justice and defense departments. A rule change resulting from the petition permitted entities receiving international signals to link directly with Comsat, thereby eliminating a cumbersome and costly intermediary service. And, as mentioned above, President Ronald Reagan deregulated the satellite communication industry in 1984, opening it to commercial competition.

Another satellite-related technology employed by SIN in the late 1970s was low-power television (LPTV), two types of which were particularly effective in reaching geographically dispersed Spanish-speakers: translator stations and repeater stations. Translators receive a satellite downlink signal, convert it to a broadcast signal, and transmit. Repeater stations receive the signal from a broadcast station via a terrestrial distribution system, mostly microwave at the time, and re-broadcast it to a smaller market. Spanish International employed LPTV in areas with concentrated Hispanic populations that were too small to support a full-power station. The smaller geographic area covered by a LPTV signal was of little concern, because urban Spanish speakers tended to concentrate in a few central neighborhoods rather than being scattered in outlying suburbs. By the mid 1980s, LPTV was delivering SIN programming to more than 500,000 Latino households located outside the broadcasting radiuses of its UHF stations (Kesler, 1986).

The important point behind these examples of applying new or underutilized technology is that Spanish International leadership-Rene Anselmo deserves principal credit-actively sought cost-effective means of reaching the network's broadly-dispersed target audience. The leadership 
sometimes countered mainstream tendencies or used technology in unconventional ways to expand SIN's reach to U.S. Hispanic households. Additionally, Spanish International management used the U.S. legal system to change satellite distribution rules in its favor and initiated its own satellite company, PanAmSat (spun-off in 1986); like the rule change, it had an impact on commercial television that reached far beyond the U.S. Spanishlanguage television sector.

\section{Spanish International's Legal Challenges and the Emergence of Competition}

In 1986, Spanish International-owned stations were forced to relinquish their broadcast licenses after the Federal Communications Commission (FCC) corroborated allegations of illegal control by a foreign national: Emilio Azcárraga Milmo, who had taken the helm of Mexico's Televisa corporation and its substantial media holdings - including the U.S. Spanish International companies - after his father (Azcárraga Vidaurreta) died in 1973. A stockholder derivative lawsuit had also been filed against Spanish International's companies in 1976, claiming mismanagement and breach of fiduciary duty; it was resolved in conjunction with the proceedings regarding illegal foreign control.

Notwithstanding the strategic acumen noted in the prior section, the unraveling of the Spanish International companies originated within the leadership (recall our discussion of internal challenges to strategic management). Two of the original U.S. investors in the enterprise, Bruce Corwin and Frank Fouce Jr., claimed that Rene Anselmo used his position as the head of both the network (SIN) and the station group (SICC) to favor the former over the latter. Investigations by the U.S. Department of Justice and a federal administrative law judge concurred in 1986, determining the SICC stations were under the illegal control of a non-national, Emilio Azcárraga Milmo, in contravention of section $310 \mathrm{~b}$ of the 1934 Communications Act. The stations were designated for forced sale. Hallmark Cards Corp. and its initial partner, First Capital Corporation of Chicago, prevailed in a courtmanaged bidding process. The investors initially acquired the station group 
alone, then paid an additional $\$ 300$ million for the programming and ad sales network (formerly called SIN, renamed Univision in 1986), including a right-of-first-refusal programming agreement with Televisa.

The principal impetus for entering the expensive programming agreement was competition, which began in 1986 when the Telemundo network emerged and started expanding into the major Spanish-speaking cities in the U.S. Yet, even with its expensive lock on imported Mexican programming, Hallmark increased the airtime Univision devoted to U.S. produced programs from approximately $6 \%$ in 1987 to nearly $50 \%$ five years later. Of course, the expansion of domestic production at both networks required significant investment, including building and/or refitting studios. In 1990, Univision relocated its headquarters from Laguna Niguel in southern California, to Miami. Telemundo's main production facilities were located in San Juan, Puerto Rico and Hialeah, Florida. This concentration of program production in South Florida raised concerns about which subgroup of the Hispanic population would influence U.S. Spanish-language television news and entertainment, especially among people of Mexican origin (Wilkinson, 2002). This and other dust-ups underscored the diversity among U.S. Hispanics, as well as the challenges implicit in knitting together a national television audience (and consumer base) with standardized programming.

A major and relatively expensive strategy was to produce domestic programs tailored to the unique experiences of U.S. Hispanics and to reflect the unique diversity of the population. A limited number of programs, such as Sabado Gigante and El Show de Cristina, were both popular with domestic viewers and distributed to other Spanish-speaking countries. However, many others, including U.S.-produced telenovelas and Spanish versions of popular English-language programs, failed to gain significant audiences. This was a central reason why Hallmark sold Univision in 1992 and why Telemundo experienced persistent financial troubles.

In sum, legal challenges to the Spanish International companies and Telemundo's emergence brought new attention to Spanish-language television from potential investors and the press, not all of it positive. Whereas 
the original Spanish International leadership was adversarial in its dealings with the courts and potential competitors, Hallmark pursued a lower-key approach, yet exhibited less patience than its predecessor in waiting for returns. The initial Telemundo leadership focused narrowly on financial issues and on expanding the network's reach during the late 1980s, largely postponing the inevitable programming issues until later. Management at both networks experienced a steep learning curve as they sought to arrange their enterprises to profit from the steady growth of the U.S. Spanishspeaking population and its spending power.

\section{Telemundo's Programming and Financial Woes}

Telemundo faced financial challenges for 15 years between its launch in 1986 and its acquisition by NBC-Universal in 2001. The costs of building a network are high, and the company's early financing schemes were less than secure. A major challenge was access to inexpensive offshore programming, a pipeline that could match Univision's long-term agreement with Televisa in Mexico.

The 1990s initiated in difficult fashion for all U.S. broadcasters, especially those that were carrying large debt burdens. Univision started the decade under the threat of involuntary bankruptcy when it missed a $\$ 10 \mathrm{mi}-$ llion interest payment and was bailed out by its corporate owner, Hallmark Cards. The network then assumed substantial debt with an ownership change in 1992, for which it borrowed about $\$ 480$ million notwithstanding the deep pockets of its principals: Jerrold Perenchio (U.S.), Emilio Azcárraga Milmo (Mexico) and Gustavo Cisneros (Venezuela). Listing on stock exchanges in 1996 raised capital the Univision leadership used effectively to redouble its competitive advantage over Telemundo during the latter 1990s.

For its part, Telemundo reported a net loss of \$275 million for 1991 and, in January 1992, failed to make payment on $\$ 250$ million in debt, placing it in default on all its outstanding debt. Subsequent restructuring talks dragged on for over a year, causing three junior investors to become impatient and petition the courts to place the company in involuntary bankruptcy in June 1993. The network emerged from Chapter 11 bankruptcy protec- 
tion in August 1993, when the parties involved agreed on a reorganization plan to reduce the company's debt from $\$ 300$ million to $\$ 115$ million (Burgi, 1993).

In November 1997, the news broke that Sony Pictures Entertainment Co. and Liberty Media Corp., the programming unit for the cable television giant Telecommunications Inc. (TCI), had joined a partnership that would acquire Telemundo for $\$ 539$ million. The two companies represented a much-needed inflow of resources and production know-how. The other partners were two venture capital companies, Apollo Management and Bastion Capital Fund, whose combined ownership share increased from $35 \%$ to $50.1 \%$ with the former holding $34 \%$ and the latter $16 \%$ (Mendoza, 1998). Given its substantial resources and programming experience, Sony became the managing partner of the network, which supplied content to the Telemundo station group. An industry observer, Jose del Cueto, commented, "... for the first time ever, Telemundo has a content component to it” (quoted in Zbar, 1997).

Programming, marketing and distribution became the principal focuses of the new Telemundo management team that took shape in August 1998. The team faced a formidable challenge, as Telemundo's share of the U.S. Spanish-language television pie had diminished from a high of $40 \%$ in 1992 to $18 \%$ when it was sold (Zbar, 1997); Univision gained significant momentum in the interim. Although Telemundo's new leadership preferred to develop U.S.-produced programs, the relatively high cost and limited time until the next TV season mitigated against it. Thus, Sony moved quickly to create Spanish-language versions of several successful Englishlanguage shows such as Starsky \& Hutch (Reyes y Rey), The Dating Game (Buscando Pareja) and Who's the Boss (Una Familia con Angel), which debuted in September 1998 (Paxman, 1998). These programs, which harkened back to the escalation of domestic programming competition in the late 1980s, fell short of reflecting the U.S. Hispanic experience, and also in

5 Peter Tortorici, a former president of CBS Entertainment, became network president; Nely Galan, who had become the New York affiliate station WNJU's general manager at only 22 years of age, became president of programming; former Sony Pictures Entertainment senior vice president of corporate development Alan Sokol assumed the role of chief executive officer; and Rachael Wells, also from Sony Pictures, became executive vice president of marketing. 
the ratings. Telemundo's audience plummeted more that $30 \%$ during the nine months after the ownership change, to reach a mere $8 \%$ of Hispanic television households (Baxter, 1998).

Sony's owning the rights to popular English-language television shows such as The Nanny, The Young and the Restless, and Wheel of Fortune meant little if they could not be adapted in ways that were compelling and meaningful to Hispanic audiences. The same was true of Liberty Media's content from regional cable channels such as Discovery Latin America, Discovery Kids Latin America, Travel Channel Latin America, Fox Sports America and the QVC home shopping network (Zbar, 1997).

We have seen that, in the beginning of the 1990s, management at both networks endeavored to keep their enterprises afloat under heavy debt burdens and a soft advertising market. The 1992 ownership change at Univision brought Emilio Azcárraga and Televisa back in, and opened another avenue for inexpensive content from Venezuela. The new management reorganized quickly, raised capital and began pounding Telemundo in the Nielsen company's Hispanic ratings. Telemundo's 1997 sale brought new production talent and resources with Sony and Liberty Media, but the network still lacked Univision's main competitive advantage, which can be understood more clearly through the resource-based view in strategic management research (Chan-Olmstead, 2003): low-cost off-shore programs. This tumultuous period in Telemundo's development, which coincided with significant growth in the U.S. Hispanic population and its buying power, ended in 2001 when NBC-Universal announced it would purchase Telemundo for $\$ 2.8$ billion.

\section{Exploiting Niches to Gain a Market Foothold}

The Hispanic sector's growing population and spending power at a time when the Telemundo network was struggling presented an expansion opportunity the Univision leadership did not pass up. A seasoned Hollywood CEO, Jerrold Perenchio, and former San Antonio mayor and Secretary of Housing and Urban Development Henry Cisneros fronted an aggressive management team that gained the company significant market share as its 
principal competitor foundered. Univision's dominance rendered entry to the market by new competitors difficult, but not impossible.

Univision's reliance on content produced in Mexico and to a lesser degree Venezuela - by Televisa and Venevision respectively_-somewhat limited the appeal of its programming to other national origin groups. Echoes were heard of long-standing complaints that Univision programming did not sufficiently address the needs or interests of U.S. Hispanics, due to limited domestic production. The language issue gained salience, as many Hispanics were bilingual or English-dominant and accustomed to consuming mainstream as well as Spanish-language television, as we will see in greater detail below. These voids demarcated opportunities for new initiatives to target as channels multiplied and potential niches within the Hispanic television market became clearer.

In the late 1980s and early 1990s, dozens of Spanish-language program services emerged to target both the U.S. sector and Latin America simultaneously, as pay television systems blossomed in the region (Wilkinson \& Garcia, 2012). In the news arena, Cable News Network (CNN), the British Broadcasting Corporation (BBC) and Reuters launched 24-hour Spanishlanguage news services. Sports television was enhanced by Spanish-language channels for the Entertainment and Sports Programming Network (ESPN) and Prime Ticket La Cadena Deportiva, which merged with Fox Sports Americas in 1996, later becoming Fox Deportes. Program services such as HBO Olé, TNT Latin America and Cine Canal offered movies, television series and specials to pay television audiences. Thus, as narrowcasting expanded apace on U.S. English-language television, parallel growth took place not only in the domestic Spanish-language sector, but throughout Spanish America as well.

Several U.S.-based channels merit discussion, as they sought to reach niche audiences that were underserved by the two major broadcast networks. GEMS, launched in 1993, targeted female audiences with telenovelas, comedy series, movies, documentaries, musicals and miniseries. Vignettes airing between the programs focused on health, beauty, travel, 
fashion, career and family (Ozemhoya, 1993b). Gary McBride, the GEMS network president (and a former Telemundo president), identified women as "undoubtedly the dominant demographic television consumer group in Hispanic households throughout Latin America and the United States" (Ozemhoya, 1993b). Most programs originated from Radio Caracas Televisión in Venezuela, which owned Coral Pictures, the company that distributed GEMS programming throughout the U.S. and Latin America, as well as Europe and the Middle East.

In 2000, GEMS became Mun2, a sister network of Telemundo. The network's target niche shifted from Spanish-dominant women to bilingual and bicultural audiences of both genders, between 18 and 34 years old, a prescient move as the 2010 U.S. Census found that more than half of U.S. Hispanics were born in the country, and $60 \%$ of Hispanics were under age 35 (Ennis, Ríos-Vargas \& Albert, 2011; Saenz, 2010). In 2005, Mun2 relocated its headquarters from Miami to Los Angeles, partly to avail itself of NBC Universal resources, but also to be located amid its principal audience: demographic, youth of Mexican origin, various generations removed. Rojas and Piñón (2014) emphasize NBC Universal's management (presently under Comcast's control) as an important factor in Mun2's trajectory. The conglomerate has effectively supported and cross-promoted Mun2 with its other media properties, especially its English-language television programs, and on line (Littleton, 2012).

Music is a television genre long holding particular appeal for adolescents and young adults, a demographic that is of particular interest to advertisers wishing to establish brand loyalty and tap youths' more liberal spending behavior. MTV's first venture into the Spanish-language market started in 1988 with MTV Internacional, a weekly program that it co-produced with Telemundo. When MTV en Español debuted in 1993, it was the sixth international network launched by Music Television and the first created without a partner (Lannert, 1993). A variety of music video shows hosted by VJs (video jockeys) and short segments of news, fashion, sports and the arts were offered 24-hours-a-day in Latin America and the U.S. (excluding Brazil, where a separate service was launched in 1990). In 2005, MTV's parent 
company, Viacom, acquired the competing Más Música network, and the following year it was merged with MTV en Español and renamed MTV Tr3s. The network targets 12 to 34 year old Latin Americans, Americans and U.S. Latinos with a pop-urban rock format (Rojas \& Piñón, 2014).

SiTV originated in 1997, producing Hispanic-oriented English-language programming that aired on the Spanish-language Galavision cable network owned by Univision. From its outset, SiTV principals Jeff Valdez and Bruce Barshop sought to create a stand-alone network geared toward English-speaking Hispanics. After several delays, SiTV launched in February 2004, airing a combination of syndicated shows and original programming. In 2011 Sí TV changed its name to NuvoTV. The network continues to broadcast in English and to focus on the youth market, calling itself "the first and only English-language television network created for American bi-cultural Latinos, 18-49" (NuvoTV, 2012). NuvoTV announced in 2012 that actress and singer Jennifer Lopez had joined as a minority investor and would contribute her creative, production and marketing talents to the network. Press releases emphasized the rising demand for English-language content among U.S. Hispanics, as well as Lopez's yearning for more Hispanic characters on English television as she was growing up (Steinberg, 2012).

The V-me network (playing on the Spanish "veme" or "watch me") was launched in 2007 as a for-profit, public-private venture between Educational Broadcasting Corp. in New York, the Baeza Group, an investment firm, and Syncom Funds, a venture capital enterprise. V-me originally was launched on 18 PBS-affiliated stations reaching an estimated 60\% of Hispanic television households; two years later, it claimed to reach $70 \%$ of such households through 40 affiliated stations (V-me rides digital, 2009). Its focus is on education and enrichment through programs centered on nature, food, current affairs, hobbies, etc. for adults, and learning for kids, including Spanish versions of successful English-language children's shows.

Several partnerships announced in 2012 demonstrated major media corporations' eagerness to gain footholds among English-speaking and 
bilingual audiences in the U.S. Mexico's Televisa and Lionsgate, the Hollywood film and television studio, are deepening an existing programming partnership with the Pantelion Films project. Televisa will create Englishlanguage programming with a Latin flair, in some instances based directly on its successful Mexican telenovelas. There were no immediate plans to produce news.

In January 2012, News Corp.s Fox International Channels Company announced a partnership with RCN network in Colombia to launch a fourth U.S. Spanish-language television network called MundoFox. The network rolled out nationally in August 2012, with station KWHY in Los Angeles serving as the flagship. $\mathrm{RCN}$ has deep experience in telenovela production, including the hits Betty La Fea ("Ugly Betty") and El Capo, both of which have aired on MundoFox. Initially, most news content will come from RCN's 24-hour news channel, NTN24, with increasing contributions from U.S. stations as the network matures.

Another major joint venture announced in 2012 is a 24-hour cable news channel called "Fusion" between $\mathrm{ABC}$ and Univision, which was launched in October 2013. Fusion's content caters to English-dominant Hispanics, with an accompanying web site and social media channels supplementing the television channel. This is new terrain for Univision, which has long reinforced the language barrier in Hispanic-oriented media. The network originated movements in this direction by offering English subtitles on its primetime telenovelas and some other shows, including $\mathrm{Sa}$ bado Gigante. However, as Alan Albarran (2012) noted, the ABC-Univision partnership faces challenges in blending their management styles and corporate cultures. An example of these differences appeared in summer 2014 when undocumented immigrant children from Central America on the U.S-Mexico border dominated the U.S. news agenda. Although we found no reports of conflict in the Fusion team, ABC News and Univision covered the story distinctly, with Univision taking an unusual activist stand by petitioning the Obama administration to protect the children and launching a humanitarian relief campaign for them (Dinan, 2014; Lines are Open, 2014). 
The accelerated movement away from broadcasting toward narrowcasting to niche audiences from the mid-1990s on represents a significant challenge to Spanish-language television management, which has had to confront the main characteristic that historically demarcated their industry segment: language. We have seen that new ventures were the first to experiment with English-language, bicultural and bilingual programming, but the larger players eventually followed suit. An important simultaneous development that facilitated the shift was digitization, which opened up new content distribution as well as advertising options, and multiplied the number of devices by which audiences could access content.

\section{Responses to Digitization}

The final period we examine corresponds to the emergence of the Internet as a consumer and entertainment medium, as well as the rapid development of interactive mobile technologies in the information age. The challenge for Spanish-language television companies has been to establish a strong presence on the World Wide Web and to make sound strategic alliances with new media companies that will point consumers to their television channels, web sites, and other media properties. In 2007, Laurel Wentz of Advertising Age succinctly described how the digital boom impacted Hispanic-oriented media:

\footnotetext{
The huge change in the Hispanic media world is the digital explosion. Hispanic print media, long digital laggards, finally have online strategies. Social networking is taking off. Online media and the Hispanic TV networks' websites are growing exponentially; Univision.com expects 5 billion page views this year. And mobile marketing is the latest catchphrase (p. S-1).
}

Before reviewing the new media advances, we should discuss an important technological and programming development in the pay television industry. With the profusion of new channel space opened through digitization, digital compression and related technologies, more channels have became available at lower cost on cable and direct-to-home television systems. Thus, Telemundo and Univision launched channels catering to niche audiences within their demographic of Spanish-speakers, and also reached 
across the language divide to attract more bilingual and English-dominant Hispanics. As we saw in the prior section, Telemundo converted its femaleoriented channel Gems to Mun2 in 2001 to attract the younger audiences coveted by advertisers. Univision launched its Telefutura service in 2002, and both networks have developed music video channels targeting the youth market. These channels are part of a broader industry trend toward narrowcasting, yet are instrumental in defining and serving a rapidly-growing population segment that has been difficult to reach and retain through lowest common denominator programming due to its geographic, linguistic and ethnic diversity. We should also note that this expansion of outlets for Hispanic-oriented programs coincided with the com boom and the Latin boom that brought increased recognition and status to U.S. Hispanic, Latin American and Iberian culture. (Unpacking the compelling relationships among those booms is a topic for separate study.)

In 1999, Univision became the first U.S. Spanish-language television network to launch its website, Univision.com, which has been cited consistently as the most widely used Spanish-language website among Hispanic Internet users (Univision.com touts ranking, 2006; Statista, 2012). Telemundo partnered with a number of Internet portals including espanol.com and quepasa.com early in the 2000s, and established a more consistent presence in 2006 when telemundo.yahoo.com was launched. Both networks' sites feature promotional material for their television shows, as well as the many links to the diverse lifestyle content one has come to expect of major Internet portals. The networks also have launched digital media divisions to reach consumers through interactive technologies, such as cellular telephones and iPods. Univision Móvil was launched in 2004 to provide mobile games, ring tones, wallpaper, audio tones, news, and mobile greeting applications. Telemundo dedicated a new division of the company to digital technology in 2005.

As in other sectors of the industry, U.S. Spanish-language television has used Internet to promote and distribute its programming. In 2010, Univision began developing online-only content with brand tie-ins. Vidas Cruzadas (Crossed Lives) was a 15-episode online-only telenovela featuring 
in-show brand integration with McDonald's, State Farm and L'Oréal (Wentz, 2011). In an effort to build on the success of Vidas Cruzadas, the network launched an Internet channel called Novelas y Series, which featured shortformat content from network programs, as well as material from other providers (Univision launches, 2010). In 2012, Univision introduced another online video initiative called UVideos Digital Network to facilitate delivery of Univision content across multiple devices, including smartphones, tablets, game consoles and Internet-enabled television receivers. Univision CEO Randy Falco claimed, in early 2013, that UVideos was accessible on more than 240 million devices (Szalai, 2013). Univision planned to develop content in a variety of program genres through more partnerships.

Univision has not ignored its core business, however. In March 2012, it debuted two genre- (and largely gender-) specific channels devoted to telenovelas ("tlnovelas") and sports ("Univision Deportes"); the appearance of both was facilitated by the settlement of a lawsuit between Televisa and Univision, and Televisa's subsequent acquisition of 5\% of Univision in 2010 (Wilkinson \& Saragoza, 2012). The network already has a strong sports presence among Hispanics through its Univision brand, but faces considerable competition from rivals Fox Deportes and ESPN Deportes.

For its part, Telemundo revamped its website in early 2009, partly to improve its video delivery capacity. In 2013, the network announced that, along with its NBC Universal sister company The Weather Channel, it would begin offering Internet and mobile applications tailored to Hispanics in both English and Spanish. Among the features customized for Hispanic audiences were weather segments hosted by Telemundo news and entertainment personalities and user options to follow weather in countries throughout Latin America (Guthrie, 2013). The network also released its "Telemundo Now" app for Internet and mobile devices, which offers programming for authenticated cable TV, satellite and telco subscribers the day after it airs on the network. This initiative also originated from within the NBC Universal conglomerate, being the fourth network to offer such a service. Marla Skiko of Starcom Mediainvest Group Multicultural, the company that launched the app for Telemundo, identified the core goal in 
commercial digital media, "We are always looking to connect our clients' brands with audiences in the video space across screens and in new and innovative ways" (Kondolojy, 2013). Notwithstanding all of these initiatives and investments, the media management scholar Alan Albarran (2013) reminds us, "Efforts to continue to monetize current and emerging digital platforms remain a huge management challenge" (p.9).

\section{Conclusion}

The general picture that emerges from this study is one of industry management facing a variety of challenges, some similar to those of the general market, and some specific to ethnic-oriented media. Financial constraints tied to macroeconomic downturns, organizational churn in the wake of ownership change, and the myriad of transformations associated with digitization and other technological developments are examples of broadly experienced challenges to television management. More specific to ethnic media are advantages derived from low-cost, limited-capability technology (the UHF band, in this case), regulatory restrictions on foreign ownership or control of broadcast stations, the need to secure steady supplies of offshore content, and understanding and adjusting to increasing cultural and linguistic diversity among the target audience. Given the breadth of factors at play over the decades covered herein, we conclude that U.S. Spanish-language television management has done a respectable job of anticipating and adjusting to key challenges.

The trend for the large players, Univision and Telemundo, has been toward conglomeration: Univision acquired Hispanic Broadcasting Corp. (HBC), the largest Spanish-language radio group in 2003, and Telemundo joined the NBC Universal group in 2001. These changes can also be seen as milestones in industry maturation, as the $\mathrm{HBC}$ merger garnered the attention of advocacy groups, congress and the press (Coffey \& Sanders, 2010), and NBC Universal's acquisition marked the first substantial investment in domestic Spanish-language television by a major mainstream U.S. media conglomerate. The proliferation of smaller niche channels around the same time, some specializing in English-language and bilingual programming, also indicates industry maturation, as sub-segments of the audience 
fell into clearer focus and more investors became eager to enter the industry. The two major networks responded to the linguistic shift, and the emergence of competitors exploiting niches, by crossing the language divide that demarcated the industry for so long.

This study's macroscopic, historical approach provides an overview of challenges facing U.S. Spanish-language television management over four decades, yet also reveals, in our view, the need for more scholarly attention to the leadership and strategic management of a dynamic industry. We echo Mierzjewska and Hollifield's (2006) appeal for more vigorous research on strategic management, and we assert that U.S. Spanish-language television -and Hispanic-oriented media more broadly - provide numerous examples of management difficulties beyond those discussed here. Certainly, the United States' fastest growing media sector, which reaches a population group that will become the majority population in key states like California and Texas by 2020 and will account for one in four U.S. residents by midcentury, deserves closer scrutiny.

\section{References}

Albarran, A. B. (2008). Defining media management. International Journal on Media Management, 10(4), 184-186.

Albarran, A. B. (2013). Media management and economics research: The first 75 years. In Albarran, A. B. (ed.). Media management and economics research in a transmedia environment (pp. 5-17). New York: Routledge.

Baxter, K. (1998, December 20). As Telemundo turns. Los Angeles Times, 8.

Burgi, M. (1993, August 2). Telemundo to operate under Chapter 11. Media Week, 3(31), 4.

Chan-Olmsted, S. M. (2003). Fundamental issues and trends in media strategy research. Journal of Media Economics \& Culture, 1(1), 9-35. 
Coffey, A. J. \& Sanders, A. K. (2010). Defining a product market for Spanish-language broadcast media: United States v. Univision Communications, Inc. and Hispanic Broadcasting. Communication Law and Policy, 15, 55-89.

Dinan, S. (2014, June 27). Univision demands Obama treat illegal immigrant children better. Washington Times. Retrieved January 26, 2013 from: http://www.washingtontimes.com/news/2014/ jun/27/univision-demands-obama-treat-illegal-immigrant-ch

Ennis, S. R., Ríos-Vargas, M. \& Albert, N. G. (2011, May). The Hispanic population: 2010. U.S. Census Bureau Brief. (\#C2010BR-04). Retrieved January 26, 2013 from http://www.census.gov/prod/ cen2010/briefs/c2010br-04.pdf

Guthrie, M. (2013, May 1). Telemundo, Weather Channel partner on new multi-platform initiative. The Hollywood Reporter. Retrieved January 24, 2013 from http://www.hollywoodreporter.com/news/ telemundo-weather-channel-partner-new-449399

Jensen, E. (2007, February 7). Public television plans a network for Latinos. New York Times. p. E1. Retrieved September 15, 2008 from Lexis-Nexis database.

Kesler, L. (1986, August 11). Low-power stations build up SIN's strength. Advertising Age, 56.

Kondolojy, A. (2013, October 22). Telemundo Now App Offers TV Everywhere. TV by the numbers. Retrieved October 31, 2013 from http://tvbythenumbers.zap2it.com/2013/10/22/telemundonow-app-offers-tv-everywhere/210816

Küng, L. (2008). Strategic management in the media: Theory to practice. Sage: Los Angeles. 
Lannert, J. (1993, February 6). MTV to beam 24-hour channel to Latin America. Billboard, 1.

Lines are open for "Estamos con los Niños," Univision's humanitarian relief effort for children at the border. (2014, September 2). BusinessWire. Retrieved may 23, 2013 from http://www.businesswire.com/news/home/20140902006510/en/Lines-Open\%E2\%80\%9CEstamos-con-los-Ni\%C3\%B1os\%E2\%80\%9DUnivision\%E2\%80\%99s\#.VD6b8syuIy4

Littleton, C. (2102, April 18). NBCU harnesses demo growth spurt: Peacock courts burgeoning young Hispanic market with its dual-lingo Mun2 cabler. Daily Variety.

Mendoza, R. (1998, June). Unwelcome competition. Hispanic Business, 14.

Mierzjewska, B. I. \& Hollifield, C. A. (2006). Theoretical approaches in media management research. In Albarran, A. B., Chan-Olmstead, S. M. \& Wirth, M. O. (eds.). Handbook of media management and economics (pp. 37-66). New York: Routledge.

NuvoTV (2012, September 12). Jennifer Lopez and NuvoTV announce exclusive creative, production and marketing partnership. mynuvotv.com. Retrieved February 16, 2013 from http://www.mynuvotv.com/jennifer-lopez

Ozemhoya, C. U. (1993, April 2). Latest Hispanic TV network builds Miramar headquarters. South Florida Business Journal, 13(32), 9.

Paxman, A. (1998, August 17). Tortorici, Galan top Telemundo exec team. Variety, 29.

Picard, R. G. (2004). Environmental and market changes driving strategic planning in media firms. In Picard, R. G. (ed.). Strategic responses to media market changes (pp. 1-17). (JIBS Research Reports, No. 2004-2). Jonkoping International Business School, Sweden. 
Piñón, J. (2007). The incursion of Azteca America into the U.S. Latino media. Unpublished Ph.D. dissertation, University of Texas at Austin.

Piñón, J. (2011). The unexplored challenges of television distribution: The case of Azteca America. Television \& New Media, 12(1), 66-90.

Rojas, V. \& Piñón, J. (2014). Spanish, English or Spanglish? Media strategies and corporate struggles to reach the second and later generations of Latinos. International Journal of Hispanic Media, 7. Retrieved February 13, 2013 from http://www.internationalhispanicmedia.org.

Saenz, R. (2010, December). Population bulletin update: Latinos in the United States 2010. Population Reference Bureau. Retrieved April 13, 2013 from www.prb.org/pdf10/latinos-update2010.pdf

Statista. (2012). Most popular Spanish-language websites in the U.S. in 2012. Retrieved february 16, 2013 from http://www.statista.com/statistics /250285/ranking-most-popular-spanish-language-sites-us/

Steinberg, B. (2012, September 12). Jennifer Lopez to take minority stake in cable's NuvoTV. Advertising Age. Retrieved February 16, 2013 from http://adage.com/article/media/jennifer-lopez-minoritystake-cable-s-nuvo-tv/237139/

Sylvie, G., Wicks, J. L., Hollifield, C. A., Lacy, S. \& Sohn, A. B. (2008). Media management: A casebook approach ( ${ }^{\text {th }}$ ed. $)$. New York: Routledge.

Univision.com touts ranking as no. 1 most visited Spanish-language website. (2006, September 18). Wireless News.

Univision launches mobile and web novelas channel. (2010, February 22). TV Technology. Retrieved February 16, 2013 from http://www. tvtechnology.com/exhibitions-\&- events/0109/univision-launches-mobile-and-web-novelas-channel/204985 
V-me rides digital transition to rank as 4th largest U.S. Hispanic broadcaster. (2009, June 12). PR Newswire. Retrieved February 15, 2013 from http://www.prnewswire.com/news- releases/v-me-ridesdigital-transition-to-rank-as-4th-largest-us-hispanic-broadcaster62105612.html

Wilkinson, K. T. (2002, Summer/Fall). Collective situational ethnicity and Latino sub-groups' struggle for influence in U.S. Spanish-language television. Communication Quarterly, 50(3/4), 422-443.

Wilkinson, K. T. \& García Castañeda, N. (2010, January/February). El flujo se intensifica: los programadores de cable estadounidenses entran a América Latina. Revista Latinoamericana de Ciencias de la Comunicación, 12(7), 12-21.

Wilkinson, K. T. \& Saragoza, A. M. (2012, Fall). Cuando potencias hegemónicas riñen: Televisa vs. Univision Communications vista a través de una lente de gestión de medios. Global Media Journal Mexico, 9, 16-34.

Wilkinson, K. T. (Forthcoming). Spanish-language television in the United States: Fifty years of development. New York: Routledge.

Zbar, J. D. (1994, January 24). Special report: Marketing to Hispanics. Advertising Age, S-4. 